\title{
Population structure of Tabapuã beef cattle using pedigree analysis
}

\author{
P.A. Bernardes ${ }^{\text {a }}$, D.A. Grossi ${ }^{a}$, R.P. Savegnago ${ }^{\text {a }}$, M.E. Buzanskas ${ }^{\text {a }}$, S.B. Ramos ${ }^{a}$, \\ E.P. Romanzini ${ }^{b}$, D.G.F. Guidolin ${ }^{c}$, L.A.F. Bezerra ${ }^{\mathrm{d}}$, R.B. Lôbo ${ }^{\mathrm{e}}$, D.P. Munari ${ }^{\mathrm{a}, *}$ \\ a Departamento de Ciências Exatas, Faculdade de Ciências Agrárias e Veterinárias, Universidade Estadual Paulista, Jaboticabal, São Paulo, Brazil \\ ${ }^{\mathrm{b}}$ Departamento de Zootecnia, Faculdade de Ciências Agrárias e Veterinárias, Universidade Estadual Paulista, Jaboticabal, São Paulo, Brazil \\ ${ }^{\mathrm{c}}$ Universidade Anhanguera, Uniderp, Campo Grande, Mato Grosso do Sul, Brazil \\ ${ }^{\mathrm{d}}$ Faculdade de Medicina de Ribeirão Preto, Universidade de São Paulo, Ribeirão Preto, São Paulo, Brazil \\ e ANCP-Associação Nacional dos Criadores e Pesquisadores, Ribeirão Preto, São Paulo, Brazil
}

\section{A R T I C L E I N F O}

\section{Article history:}

Received 3 November 2015

Received in revised form

3 March 2016

Accepted 4 March 2016

\section{Keywords:}

Effective number of founders

Effective population size

Inbreeding

Pedigree completeness

\begin{abstract}
A B S T R A C T
This study evaluated a Tabapuã population structure and the linear relationship of the inbreeding coefficient with phenotypic values of weaning weight adjusted to 210 days of age (W210); age at first calving (AFC); first (CI1), second (CI2) and average (ACI) calving intervals; and, accumulated productivity (ACP). The phenotypic data used were from 7340 cows and the pedigree file had 15,241 animals. The average pedigree completeness of the last six generations was $47.99 \%$. The effective numbers of founders and ancestors were 124 and 110 , respectively, with a ratio of 1.13 . These results suggested the absence of the genetic bottleneck effect. The inbreeding coefficient increased over generations and the average was 0.007. The effective population size became small in the last generation. The regression analysis results of phenotypic values for inbreeding coefficients were not significant $(P>0.05)$ for W210, CI1 and ACP; and, significant $(P<0.05)$ and favorable for AFC, ACI and $\mathrm{CI} 2$. The results indicated that mating between related animals and the intensive use of few breeders should be avoided. Regression analysis indicated no inbreeding depression, which can be justified by the fact that inbreeding is not yet strongly established.

(c) 2016 Elsevier B.V. All rights reserved.
\end{abstract}

\section{Introduction}

Tabapuã is a zebu beef cattle breed originated in Brazil highly adapted to tropical environmental conditions. The breed was originating by crossing breeds such as the Brazilian polled cattle, Gir, Guzerah and Nelore and had official recognition in 1981 (Silva Filho et al., 2012; ABCT, 2016). The animals born before 1981 were considered as a new type of Indian cattle. The entire current herd descended from only one bull, characterizing the uniformity observed in herds (ABCT, 2016). A possible consequence of using only one bull would be the reduced genetic variability of a population.

The use of reproduction biotechnologies, such as artificial insemination, embryo transfer and in vitro fertilization, which are used in the Brazilian production system, if used with prudence, allows reducing the generation interval while increasing the number of animals in the herd and selection intensity. Therefore, genetic gain could be achieved. However, when selection intensity increases, the number of animals used as breeders could be

\footnotetext{
* Corresponding author. Tel.: +55 1632097212.

E-mail address: danisio@fcav.unesp.br (D.P. Munari).
}

restricted and, consequently, increased inbreeding and reduced genetic variability may affect animals' fertility. In addition, it might reduce average phenotypic performance of some economically important traits, known as inbreeding depression (Falconer and Mackay, 1996).Due to its negative effects, inbreeding should be monitored in beef cattle breeding programs, to ensure that the selection results outweigh the effects of inbreeding depression, as reported by Pariacote et al. (1998) for Hereford cattle.

Besides the control of inbreeding, the knowledge of population structure is necessary, which allows implementing and monitoring a selection program with success. The differences in genetic variability observed between some populations can be related to population size, breeding policy, and selection objectives (Gutiérrez et al., 2003). In fact, population parameters, such as number of founders, number of ancestors, genetic drift and population size can alter the genetic variability and according Verrier et al. (1993) methods that preserve genetic variability can provide higher final cumulative gains in a selection program for small populations. Therefore, the objective of this study was to assess the population structure of Tabapuã cattle using pedigree records, and to access the impact of the use of few bulls on the genetic variability of the population, inbreeding and phenotypic performance of the 
animals over generations.

\section{Materials and methods}

\subsection{Description of the dataset}

The Genetic Breeding Program of the Tabapuã Breed (Programa de Melhoramento Genético da Raça Tabapuã, PMGRT) maintained by the National Association of Breeders and Researchers (ANCP) supplied all the data used in the study. Phenotypic records of 7340 cows born between 1970 and 2011 and the pedigree of 15,241 Tabapuã animals, born between 1958 and 2011, in São Paulo, Bahia, Minas Gerais, Mato Grosso do Sul, Mato Grosso, Goiás, Tocantins and Paraná states were analyzed. The dataset used for analysis of population structure is described in Table 1 . The traits used in the regression analysis were weaning weight adjusted to 210 days of age (W210); age at first calving (AFC); first (CI1), second ( $\mathrm{Cl} 2$ ), and average ( $\mathrm{ACI}$ ) calving interval; and accumulated productivity (ACP).

The ACP is an index expressed as weight, in kilograms, of calf weaned per cow per year, directly related to age at first calving, calving interval and weaning weight. It is calculated as: ACP = $\left(W_{w} \times n_{c} \times 365\right) /\left(\mathrm{ACC}_{n}-550\right)$ (Lôbo et al., 2000), wherein $W_{w}$ is the average weight of calves at weaning standardized to 210 days of age; $n_{c}$, total number of calves produced; a constant equal to 365 days allowing to express fertility on an annual basis; ACC $_{n}$ is the age of the cow (in days) at the last calving, and a constant equal to 550 days, considering that the goal of the PMGRT for the age at first calving is 30 months (Lôbo et al., 2000), with a minimum breeding age of 18 months. The descriptive statistics for those traits are in Table 2.

\subsection{Pedigree analysis}

The pedigree records were used to estimate the population structure such as pedigree completeness; effective number of founders and ancestors; ratio of the effective number of founders and ancestors; average relatedness and inbreeding coefficients; and, effective population size, using the ENDOG 4.8 software (Gutiérrez and Goyache, 2005). This software requires pedigree sequential numbering, which was obtained using the CFC software (Sargolzaei et al., 2006).

\subsection{Pedigree completeness}

The pedigree completeness identifies how much of the pedigree is complete in each generation, and can be calculated from the amount of information that is unknown, i.e., the amount of the parents' records that is absent. The number of generations contributes to assessing the pedigree completeness and can be calculated in three ways: number of full generations given as the

Table 1

Pedigree structure of Tabapuã cattle.

\begin{tabular}{lr}
\hline Total number of animals & 15,241 \\
Total number of females & 11,911 \\
Total number of males & 3330 \\
Number of sires & 1058 \\
Number of dams & 8116 \\
Animals with progeny & 9174 \\
Animals without progeny & 6067 \\
Animals with only sire unknown & 611 \\
Animals with only dam unknown & 143 \\
Males with sire and dam unknown & 200 \\
Females with sire and dam unknown & 1798 \\
\hline
\end{tabular}

Table 2

Number of animals $(N)$, mean and standard deviation (SD) for the studied traits.

\begin{tabular}{|c|c|c|c|}
\hline Trait & $N$ & Mean & SD \\
\hline W210 (kg) ${ }^{\mathrm{a}}$ & 3192 & 178.99 & 27.09 \\
\hline $\mathrm{AFC}$ (months) ${ }^{\mathrm{b}}$ & 5197 & 37.76 & 5.75 \\
\hline $\mathrm{ACI}(\text { days })^{\mathrm{c}}$ & 2582 & 505.35 & 96.29 \\
\hline CI1 (days) ${ }^{d}$ & 2582 & 524.64 & 120.38 \\
\hline $\mathrm{CI} 2$ (days) $^{\mathrm{e}}$ & 1715 & 483.44 & 113.79 \\
\hline ACP (kg weaning calves/dam/year $)^{\mathrm{f}}$ & 1077 & 144.21 & 29.06 \\
\hline
\end{tabular}

${ }^{\mathrm{a}} \mathrm{W} 210=$ weaning weight adjusted to 210 days of age

${ }^{\mathrm{b}} \mathrm{AFC}=$ age at first calving.

${ }^{\mathrm{c}} \mathrm{ACI}=$ average calving interval.

${ }^{\mathrm{d}} \mathrm{Cl} 1=$ first calving interval.

e $\mathrm{CI} 2=$ second calving interval.

${ }^{\mathrm{f}} \mathrm{ACP}=$ accumulated productivity.

number of generations in which both parents are known; number of maximum generations, the total number of possible generations whether parents are known or unknown; and number of equivalent generations, expressed as the summation $(1 / 2)^{n}$, wherein $n$ is the number of generations in which the animal is separated from each ancestor with a known record (Maignel et al., 1996). The comparison between the numbers of full and maximum generations allows checking the completeness of the pedigree information, because close numbers for both indicate the existence of few unknown animals in the entire pedigree.

\subsection{Effective number of founders}

Animals with unknown sire and dam were considered founders. The effective number of founders $\left(f_{e}\right)$ is determined as the expected number of founders, which contributed equally with genetic material to form the population and represents the entire genetic variability of the studied population (Lacy, 1989). This parameter was calculated as $f_{e}=1 / \sum_{k=1}^{f} q_{k}^{2}$, where $q_{k}$ is the probability of origin of the gene of the $k_{t h}$ ancestor. The probability of origin of the gene and the contribution of founders were calculated using the algorithms proposed by Boichard et al. (1997).

\subsection{Effective number of ancestors}

The effective number of ancestors $\left(f_{a}\right)$ is determined by the minimum number of ancestors, founders or not, that explain the genetic diversity of the studied population (Boichard et al., 1997). This parameter was calculated as $f_{a}=1 / \sum_{j=1}^{a} q_{j}^{2}$, wherein $q_{j}$ is the marginal contribution of the $j_{t h}$ ancestor. The marginal contribution is the additional genetic contribution made by an ancestor that was not explained by another previously chosen ancestor (Boichard et al., 1997).

\subsection{Ratio of the effective numbers of founders and ancestors}

The ratio between the effective number of founders and ancestors $\left(f_{e} / f_{a}\right)$ helps to identify whether the use of breeders resulted in a genetic bottleneck. Values equal or close to one, indicate no genetic bottleneck in the population, while for values greater than one, the effective number of founders is larger than that of the ancestors, indicating possible genetic bottleneck.

\subsection{Population parameters related to inbreeding coefficient}

\subsubsection{Average relatedness coefficient}

The average relatedness coefficient for each individual is the probability that a randomly selected allele from the population 
belongs to a certain animal. This coefficient may be interpreted as the animal representation in the pedigree (Goyache et al., 2003; Gutiérrez et al., 2003; Gutiérrez and Goyache, 2005). According to Gutiérrez et al. (1990), this parameter is calculated as the average of coefficients in the row of the numerator relationship matrix, $\boldsymbol{A}$, corresponding to the individual.

\subsubsection{Inbreeding coefficient}

The inbreeding coefficient is the probability of an individual having two identical alleles by descent and was calculated using the algorithm developed by Meuwissen and Luo (1992). The increase of inbreeding per generation was calculated as $\Delta F=\left(F_{t}-F_{t-1}\right) /\left(1-F_{t-1}\right)$, in which $F_{t}$ and $F_{t-1}$ are the average inbreeding in $t_{t h}$ and $t_{t h-1}$ generations, respectively (Wright, 1931).

\subsubsection{Effective population size}

The effective population size $\left(N_{e}\right)$ is the number of individuals that contributed effectively by leaving descendants, transmitting genes to the next generation and maintaining genetic diversity (Wright, 1931). $N_{e}$ was calculated as $N_{e}=1 / 2 \Delta F$ and represents the number of animals, which while also contributing to the next generation, would promote the same increase of inbreeding observed in the studied population (Gutiérrez and Goyache, 2005).

\subsection{Inbreeding effects on phenotypic performance}

To evaluate the effect of inbreeding on the phenotypic performance of the animals, we performed linear regressions using the records of traits (W210, AFC, CI1, CI2, ACI and ACP) over the individual inbreeding coefficient, using the SAS software (SAS 9.1, SAS Institute Cary, NC, USA). The null hypothesis, in which the regression coefficient is not different from zero, was tested using the $t$-statistic at $\alpha=0.05$.

\section{Results and discussion}

\subsection{Pedigree completeness}

The pedigree completeness analysis revealed five full, 16 maximum and 6.66 equivalent generations. In this population, there was great difference between the number of full and maximum generations, which indicates that there was loss of genealogical information between individuals of the pedigree, i.e., a considerable proportion of the parents were unknown, a fact confirmed by the low maximum value of equivalent generations. Santana et al. (2010) and Danchin-Burgue et al. (2012) studied Nellore and dairy cattle populations, respectively, and suggested that the lack of information in pedigree data may cause both inbreeding coefficients of older animals and average population to be underestimated.

Fig. 1 depicts the amount of pedigree information per generation, represented by the first (older animals) and last (recent animals) generations, respectively. For the number of maximum generations, information between the first and last generation ranged from $6 \times 10^{-7} \%$ to $84 \%$ of completeness, with an average of $47.99 \%$ of completeness for the last six generations, represented by animals born between 1971 and 2011. The average pedigree information from the first to the tenth generation was less than the average pedigree information of the last six generations, which indicates lack of pedigree information of the older animals.

The genealogical records of Tabapuã animals began in 1971, although Tabapuã was still not considered a breed (Santiago, 1985). This fact might help explain the lack of information about animals born prior to this date. Caires et al. (2012) studied a smaller number of animals from Tabapuã population and also

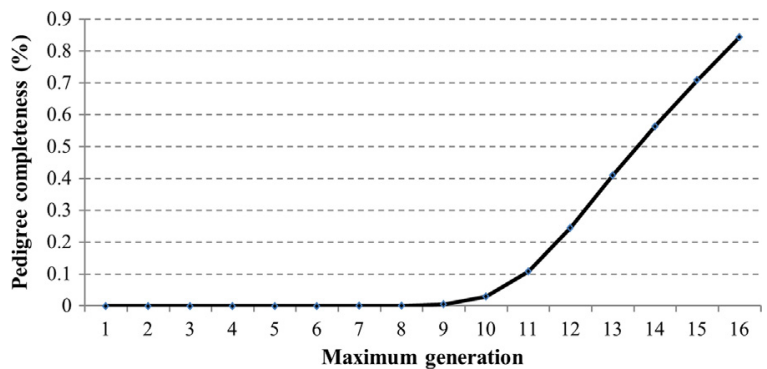

Fig. 1. Pedigree completeness (percentage) along 16 generation obtained by calculation for maximum generation to a population of Tabapuã cattle. The first generation contain the oldest animals and the last generation contain the most recent animals.

found few pedigree records for the older generations.

\subsection{Effective number of founders}

The study population had a total of 1998 animals (200 males and 1798 females) with unknown sire and dam (founders - Table 1). The contribution of the founders to the genetic variability of the population ranged from $0.006 \%$ to $5.238 \%$. The difference between the contributions of founders may be due to intensive use of few animals at the beginning of breed formation, wherein was possible observed that of all founders (born from 1958 to 2010), animals born before 1981 contributed $40.72 \%$ of the genetic variability of the population. One male founder was the major contributor to the genetic variability of the population. Regarding the female founder, $0.99 \%$ was the greatest contribution to the genetic variability. The difference observed between the contributions of males and females may have resulted from the intensive use of few bulls. Peixoto et al. (2010) identified one sire ( $4.15 \%$ contribution) as the greatest contributor to the variability of Guzerah cattle population.

The effective number of founders was 124 . The smaller number of female founders (1) compared to males (9) was observed among the 10 animals that most contributed due to the intense use of few breeders to form this population. This imbalance in reproduction of founders can also be observed by the low effective number of founders (124) compared to the total number of animals with unknown sire and dam (1998 founders). As a result, few animals explained almost all of the genetic variability within the population.

Similarly, Vercesi Filho et al. (2002a) reported the effective number of founders of the Tabapuã breed ranging from 112 to 218, evaluated every four years between 1979 and 1998. Caires et al. (2012) obtained 164 effective founders for the same breed. These differences may be due to the use of animals from different years and different regions from Brazil. Caires et al. (2012) observed $3.72 \%$ of variability explained by the most important founder in northeastern of Brazil, which is lower compared to $5.238 \%$ obtained in present study, representing that few founders have great contribution to genetic variability. The effective number of founders reported for Indubrasil was higher (479 to 607), as reported for Nellore that ranged from 181 to 458 animals (Vercesi Filho et al., 2002b; Brito et al., 2013). The differences between the values in the literature and this study may be explained by the recent formation of the Tabapuã breed.

\subsection{Effective number of ancestors and the ratio between the effective number of founders and ancestors}

The effective number of ancestors was equal to 110 . The 10,20 and 55 ancestors that most contributed to the genetic diversity of the population accounted for $21 \%, 31 \%$ and $50 \%$ of the genetic 


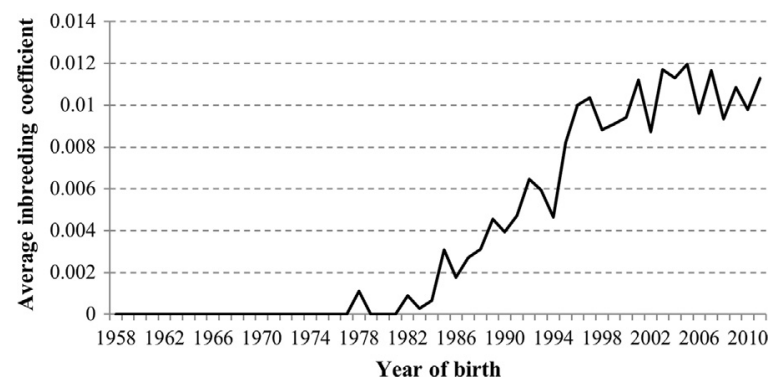

Fig. 2. Average inbreeding coefficient per year of birth among Tabapuã cattle.

variability, respectively. The ratio between the effective number of founders and ancestors $\left(f_{e} / f_{a}\right)$ was 1.13 and indicates that the variability of this population was not affected by a genetic bottleneck. Vercesi Filho et al. (2002a) reported similar result for a cattle population of the same breed. Peixoto et al. (2010) reported a ratio of 3.15 for a Guzerah cattle population with higher number of founders compared to this study, thus concluding that the $\mathrm{Gu}-$ zerah population was affected by a genetic bottleneck.

\subsection{Population parameters related to inbreeding coefficient}

The average inbreeding coefficient of the studied population was 0.007. Fig. 2 depicts the average annual inbreeding coefficient for animals born by year. The increase for inbreeding in complete, maximum and equivalent generations was $0.37 \%, 0.14 \%$ and $0.26 \%$, respectively. When pedigree information is scarce, these values inform the upper, lower, and "real" limits, respectively, for estimations (Gutiérrez and Goyache, 2005). The average inbreeding coefficient for Tabapuã was lower than those for Nellore, Gir, and Guzerah populations studied by Faria et al. (2009) and this may be due to differences in pedigree completeness that was lower for Tabapuã. Boichard et al. (1997) reported that the inbreeding coefficient may be underestimated even with a small proportion of unknown pedigree (10\%). In addition, selection methods that favor related individuals and techniques that use few bulls, such as artificial insemination, have been used in Nellore, Gir and Guzerah for a longer time. These approaches tend to increase the average inbreeding coefficient for these three breeds that were recognized before Tabapuã breed.

Although the information on the animals have began in 1971, as noted in the pedigree completeness, the inbreeding coefficient increased only from 1981, i. e., when Tabapuã was officially recognized as a breed and possibly spreading this breed by producers who valued breeding winners in exhibitions. The number of animals, average inbreeding coefficient, percentage of inbred animals, inbreeding coefficient for inbred animals and average relatedness (Table 3) were presented per complete generation since it is more informative compared to other calculated generations.

The increase in inbreeding coefficient, in average relatedness and in inbred animals over the full generations can be the

\section{Table 3}

Number of animals for generation $(N)$, average inbreeding coefficient $(F)$, percentage of inbred animals, inbreeding coefficient for inbred animals and average relatedness (AR) for complete generation to a population of Tabapuã cattle.

\begin{tabular}{lrllll}
\hline $\begin{array}{l}\text { Complete } \\
\text { generation }\end{array}$ & $N$ & $F$ & $\begin{array}{l}\text { Inbred ani- } \\
\text { mals (\%) }\end{array}$ & $\begin{array}{l}\text { F coefficient for } \\
\text { inbred animals }\end{array}$ & AR \\
\hline 0 & 2752 & 0.0000 & 0.0000 & 0.0000 & 0.0010 \\
1 & 3184 & 0.0012 & 0.0267 & 0.0456 & 0.0064 \\
2 & 3694 & 0.0106 & 0.3563 & 0.0297 & 0.0107 \\
3 & 3904 & 0.0121 & 0.6806 & 0.0177 & 0.0138 \\
4 & 1638 & 0.0110 & 0.8431 & 0.0130 & 0.0149 \\
5 & 69 & 0.0183 & 1.0000 & 0.0183 & 0.0157 \\
\hline
\end{tabular}

consequence of the breed spreading among the producers that used few bulls for artificial insemination. Increased inbreeding over generations has been also reported in other studies with Tabapuã (Vercesi Filho et al., 2002a; Caires et al., 2012), with values similar to those of this study. Increased inbreeding over generations was also observed in Jordan indigenous cattle, Nellore and Guzerah (Al-Atiyat, 2009; Faria et al., 2009; Peixoto et al., 2010), respectively.

Although the amount of inbred animals has increased over the full generations, the average inbreeding of these animals decreased, indicating that mating between related animals has been carefully avoided. The effective population size, based on the number of full generations, was 410.6 animals for the first generation and 79.3 for generation the fifth generation. FAO (1998) considers population at a critical level when the effective size is less than 50 animals per generation. Therefore, this population is not at a critical level, but this parameter should be controlled to avoid the decreasing. The effective sizes per full generation observed in present study were similar to the range from 55 to 378 animals per generation reported for Tabapuã by Vercesi Filho et al. (2002a). The effective population size in the first full generation (410.6 animals) was similar to the 483 animals reported by Caires et al. (2012) for the same breed. Thus, producers and breeding programs should avoid intense use of few bulls to avoid reducing genetic variability of Tabapuã cattle.

\subsection{Inbreeding effects on phenotypic performance}

The mean W210 was $178.99 \pm 27.09 \mathrm{~kg}$, with the inbreeding coefficient varying from 0 to 0.26 and mean $0.01 \pm 0.02$. The $t$ statistic analysis was not significant $(P>0.05)$ for the regression coefficient and indicated no influence of inbreeding effect on the W210. The low average inbreeding coefficient estimate, as well as the low representation of highly inbred animals, may have resulted in the inbreeding not influencing the W210.

Studies with Gir (Queiroz et al., 2000), Alentejo (Carolino and Gama, 2008), Marchigiana and Bonsmara (Santana et al., 2012) identified significant unfavorable linear or quadratic effect of inbreeding on weaning weight $(P<0.05)$. However, the authors obtained mean inbreeding coefficient higher than those in this study. Santana et al. (2010) studied Nellore and also identified effect of inbreeding variation on the weaning weight. Although the average coefficient of inbreeding was close to that obtained in this study, the maximum was higher and had 61 animals with inbreeding coefficient greater than 0.25 , while this study had only 6 animals with coefficient greater than 0.25 .

The regression analyses to $\mathrm{AFC}, \mathrm{ACI}, \mathrm{CI} 1$ and $\mathrm{CI} 2$ used, respectively, $5197 ; 2582 ; 2582 ; 1715$ phenotypic records with averages of $37.76 \pm 5.75$ months, $505.35 \pm 96.29, \quad 524.64 \pm 120.38$ and $483.44 \pm 113.79$ days. The average inbreeding coefficient was $0.01 \pm 0.02$ varying from 0 to 0.26 for animals with AFC records, and equal to $0.01 \pm 0.02$ ranging from 0 to 0.16 for animals with $\mathrm{ACI}, \mathrm{CI} 1$ and $\mathrm{CI} 2$ records. The t-statistic analysis was not significant $(\mathrm{P}>0.05)$ for the regression coefficient of $\mathrm{CI} 1$ and significant $(P<0.05)$ for the regression coefficient for $\mathrm{AFC}, \mathrm{ACI}$ and $\mathrm{CI} 2$ (Fig. 3). The absence of a negative inbreeding influence on the variation of performance traits can be justified by the fact that inbreeding is not yet strongly established among animals, verified by the low average inbreeding coefficient. Although the selection program by Tabapuã is recent, the planning to form the breed and the choice by producers of superior animals to be reproducers, may have influenced to inbred animals had presented superior phenotypic performance for AFC, ACI and CI2. This result was not observed with respect of $\mathrm{CI} 1$, because this trait requires higher energy for lactation, growth and persistence of the estrous cycle from cows that calved for the first time (Cunningham, 2007), 

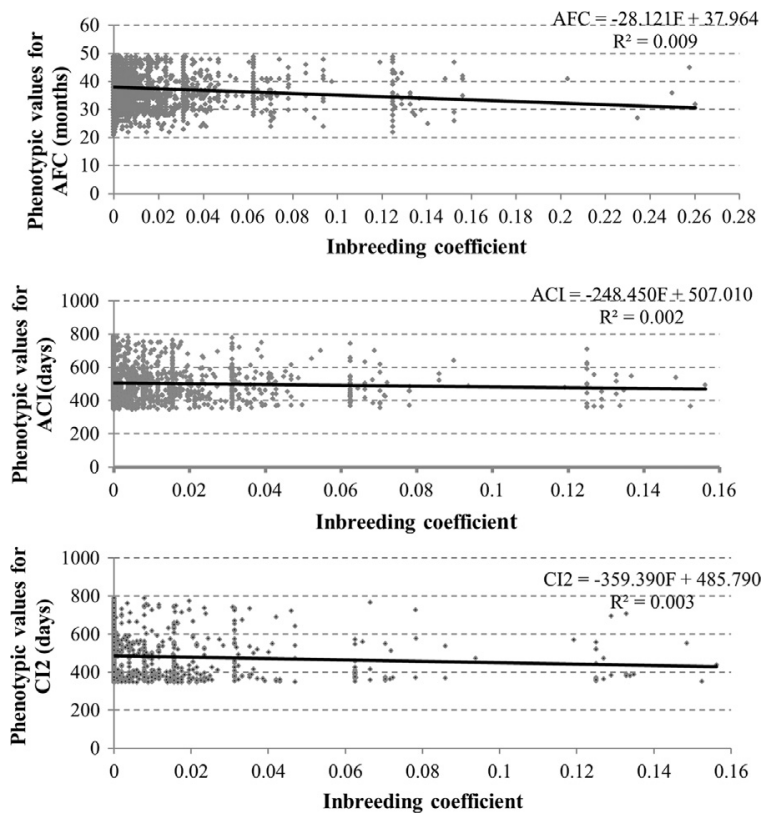

Fig. 3. Linear regression of phenotypic values, based on inbreeding coefficient $(F)$, for age at first calving (AFC), average calving interval (ACI) and second calving interval (CI2) among Tabapuã cattle. The regression coefficients were significantly different $(P<0.05)$ from zero using the $t$-statistic.

making it difficult to improve its performance without a selection program.

Panetto et al. (2010) reported inbreeding depression on AFC and CI for Guzerah cattle, and Rokouei et al. (2010) found significant $(P<0.05)$ unfavorable inbreeding effect on AFC and $\mathrm{CI}$ in the third calving in Holstein cows. The selection has been practiced for much longer in Holstein cows compared to Tabapuã and over the years the inbreeding coefficient increased, leading to changes in the performance traits. Mc Parland et al. (2007) identified adverse inbreeding effect on AFC and CI for Holstein; however, inbreeding depression of the other traits was more expressive. The authors found that even high inbreeding levels can cause small changes in phenotypic performance traits.

The 1077 phenotypic records used to calculate ACP obtained an average of $144.21 \pm 29.06 \mathrm{~kg}$ calf/cow/year. The average inbreeding coefficient was $0.01 \pm 0.02$ with a range between 0 and 0.23 . The $t$-statistic analysis result was not significant $(P<0.05)$ for the regression coefficient and indicated no influence of inbreeding on ACP performance.

The average inbreeding coefficient observed for animals that had ACP record was low. The influence of the of dam's inbreeding coefficient on W210 was not tested, nor the inbreeding effect on the number of calves produced or cow age at last calving, which are traits that compose the index. However, the $t$-statistic for the regression coefficient suggests no influence of inbreeding on these features when combined to form the ACP. Nonetheless, separate analysis of the traits may indicate inbreeding effect as reported by Carolino and Gama (2008), who observed great influence on the total calves produced over the life of the animal, wherein the inbreeding depression was more significant for this trait than for AFC.

The increasing inbreeding coefficient over the generations resulted from the increasing number of inbred animals, not from the increasing average inbreeding coefficient between inbred animals (Table 3). This factor contributed to the absence of inbreeding depression for the traits studied, since the average of the inbreeding coefficient were low, with many animals with small inbreeding coefficients and few animals with higher coefficients.

\section{Conclusion}

The results indicated that is recommended the Tabapuã producers and breeding programs continue to control the mating of related animals, avoid the intensive use of few breeders and encourage the introduction and evaluation of new breeders to increase population genetic diversity, effective size, reduce inbreeding and possible adverse consequences for the population.

\section{Conflict of interest statement}

The authors Priscila Bernardes, Daniela Grossi, Rodrigo Savegnago, Marcos Buzanskas, Salvador Ramos, Eliéder Romanzini, Diego Guidolin, Luiz Bezerra, Raysildo Lôbo and Danisio Munari wish to confirm that there are no known conflicts of interest associated with this publication and there has been no significant financial support for this work.

\section{Acknowledgments}

We thank the ANCP- National Breeders' and Researchers' Association for providing the data set used in this study. P. A. Bernardes received scholarship from the São Paulo Research Foundation (Fundação de Amparo à Pesquisa do Estado de São Paulo FAPESP - process numbers 2013/09364-5) and from the National Council for Scientific and Technological Development (Conselho Nacional de Desenvolvimento Científico e Tecnológico - CNPq). E. P. Romanzini received scholarship from CNPq (process number 131978/2014-4). S. B. Ramos received pos-doctoral fellowship from Brazilian Federal Coordination of Higher Education (Coordenação de Aperfeiçoamento de Pessoal de Nível Superior - CAPES). R. P. Savegnago and M. E. Buzanskas received pos-doctoral fellowship from the FAPESP (fellowship numbers 2013/20091-0 and 2013/ 19335-2). D. P. Munari held productivity research fellowship from CNPq (fellowship number 306888/2014-9).

\section{References}

ABCT: Associação Brasileira dos Criadores de Tabapuã - ABCT, 2016. História da raça Tabapuã. 〈http://tabapua.org.br/raca-tabapua/historia-da-raca/〉. (Accessed 18.01.16).

Al-Atiyat, R.M., 2009. Extinction probabilities of Jordan indigenous cattle using population viability analysis. Livest. Sci. 123, 121-128.

Boichard, D., Maignel, L., Verrier, É., 1997. The value of using probabilities of gene origin to measure genetic variability in a population. Genet. Sel. Evol. 29, 5-23.

Brito, F.V., Sargolzaei, M., Braccini Neto, J., Cobuci, J.A., Pimentel, C.M., Barcellos, J., Schenkel, F.S., 2013. In-depth pedigree analysis in a large Brazilian Nellore herd. Genet. Mol. Res, 12, 5758-5765.

Caires, D.N., Malhado, C.H.M., Souza, L.A., Teixeira Neto, M.R., Carneiro, P.L.S., Martins Filho, R., 2012. Tabapuã breed in Northeastern Brazil: genetic progress and population structure. Rev. Bras. Zoot 41, 1858-1865.

Carolino, N., Gama, L.T., 2008. Inbreeding depression on beef cattle traits: estimates, linearity of effects and heterogeneity among sire-families. Genet. Sel. Evol. 40, $511-527$.

Cunningham, J.G., 2007. Textbook of Veterinary Physiology, fourth ed. Saunders Elsevier, St. Louis, USA.

Danchin-Burgue, C., Leroy, G., Brochard, M., Moureaux, S., Verrier, E., 2012. Evolution of the genetic variability of eight French dairy cattle breeds assessed by pedigree analysis. J. Anim. Breed. Genet. 129, 206-217.

Falconer, D.S., Mackay, T.F.C., 1996. Introduction to Quantitative Genetics, fourth ed. Longman House, Harlow, UK

FAO: Food and Agriculture Organization - Secondary guidelines for development of national farm animal genetic resources management plans: management of small populations at risk. 1998. FAO. Rome, Italy, Disponível em: 〈http://www fao.org/ag/againfo/programmes/pt/lead/toolbox/Indust/sml-popn.pdf > >. Acesso em: 24 de junho de 2014 . 
Faria, F.J.C., Filho, A.E.V., Madalena, F.E., Josahkian, L.A., 2009. Pedigree analysis in the Brazilian Zebu breeds. J. Anim. Breed. Genet. 126, 148-153.

Goyache, F., Gutiérrez, J.P., Fernández, I., Gómez, E., Álvarez, I., Díez, J., Royo, L.J. 2003. Using pedigree information to monitor the genetic variability of endangered populations: the Xalda sheep breed of Asturias as an example. J. Anim. Breed. Genet. 120, 95-103.

Gutiérrez, J.P., Altarriba, J., Díaz, C., Quintanilla, A.R., Cañon, J., Piedrafita, J., 2003. Genetic analysis of eight Spanish beef cattle breeds. Genet. Sel. Evol. 35, 43-64.

Gutiérrez, J.P., Cañon, J., Rico, M., 1990. Aplicacion de un metodo modificado de calculo del coeficiente de consanguinidad en una muestra del ganado vacuno Frison Español. Arch. Zoot 39, 3-8.

Gutiérrez, J.P., Goyache, F., 2005. A note on ENDOG: a computer program for analysing pedigree information. J. Anim. Breed. Genet. 122, 172-176.

Lacy, R.C., 1989. Analysis of founder representation in pedigrees: founder equivalent and founder genome equivalents. Zoo Biol. 8, 111-123.

Lôbo, R.B., Bezerra, L.A.F., Oliveira, H.N., Garnero, A.V., Schwengber, E.B., Marcondes, C.R., 2000. Avaliação Genética de Animais Jovens, Touros e Matrizes: Sumario, SP, Ribeirão Preto SP, Ribeirão Preto, Brazil.

Maignel, L., Boichard, D., Verrier, E., 1996. Genetic variability of French dairy breeds estimated from pedigree information. Interbull Bull. 14, 49-54.

Mc Parland, S., Kearney, J.F., Rath, M., Berry, D.P., 2007. Inbreeding effects on milk production, calving performance, fertility, and conformation in Irish HolsteinFriesians. J. Dairy Sci. 90, 4411-4419.

Meuwissen, T.I., Luo, Z., 1992. Computing inbreeding coefficients in large populations. Genet. Sel. Evol. 24, 305-313.

Panetto, J.C.C., Gutiérrez, J.P., Ferraz, J.B.S., Cunha, D.G., Golden, B.L., 2010. Assessment of inbreeding depression in a Guzerat dairy herd: effects of individual increase in inbreeding coefficients on production and reproduction. J. Dairy Sci. 93, 4902-4912.

Pariacote, F., Van Vleck, L.D., Mc Neil, M.D., 1998. Effects of inbreeding and heterozygosity on preweaning traits in a closed population of Herefords under selection. J. Anim. Sci. 76, 1303-1310.

Peixoto, M.G.C.D., Poggian, C.F., Verneque, R.S., Egito, A.A., Carvalho, M.R.S., Penna,
V.M., Bergmann, J.A.G., Viccini, L.F., Machado, M.A., 2010. Genetic basis and inbreeding in the Brazilian Guzerat (Bos indicus) subpopulation selected for milk production. Livest. Sci. 131, 168-174.

Queiroz, S.A., Albuquerque, L.G., Lanzoni, N.A., 2000. Efeito da endogamia sobre características de crescimento de bovinos da raça Gir no Brasil. Rev. Bras. Zoot 29, 1014-1019.

Rokouei, M., Torshizi, R.V., Shahrbabak, M.M., Sargolzaei, M., Sørensen, A.C., 2010. Monitoring inbreeding trends and inbreeding depression for economically important traits of Holstein cattle in Iran. J. Dairy Sci. 93, 3294-3302.

Santana Jr, M.L., Oliveira, P.S., Pedrosa, V.B., Eler, J.P., Groeneveld, E., Ferraz, J.B.S., 2010. Effect of inbreeding on growth and reproductive traits of Nellore cattle in Brazil. Livest. Sci. 131, 212-217.

Santana Jr, M.L., Oliveira, P.S., Eler, J.P., Gutiérrez, J.P., Ferraz, J.B.S., 2012. Pedigree analysis and inbreeding depression on growth traits in Brazilian Marchigiana and Bonsmara breeds. J. Anim. Sci. 90, 99-108.

Santiago, A.A., 1985. Zebu na India, no Brasil e no mundo. Instituto Campineiro de Ensino Agricola, Campinas, p. 744.

Sargolzaei, M., Iwaisaki, H., Colleau, J. J., 2006. CFC: a tool for monitoring genetic diversity. In: Proceedings in 8th World Congress on Genetics Applied to Livestock Production, Belo Horizonte (Brazil), 13-18 August 2006.

Silva Filho, E., Silva, M.H., Campelo, J.E.G., Harada, M.L., DeRosia, M.R., 2012. Genetic characterization of a bovine breed (Tabapua) under artificial selection located in the amazon region. Am. J. Anim. Vet. Sci. 7, 226-232.

Vercesi Filho, A.E., Faria, F.J.C., Madalena, F.E., Josahkian, L.A., 2002a. Estrutura populacional do rebanho Tabapuã registrado no Brasil. Arq. Bras. Med. Vet. Zoot 54, 609-617.

Vercesi Filho, A.E., Faria, F.J.C., Madalena, F.E., Josahkian, L.A., 2002b. Estrutura populacional do rebanho Indubrasil registrado no Brasil. Arch. Latinoamericanos. Prod. Anim. 10, 86-92.

Verrier, E., Colleau, J.J., Foulley, J.L., 1993. Long-term effects of selection based on the animal model BLUP in a finite population. Theor. Appl. Genet. 87, 446-454. Wright, S., 1931. Evolution in Mendelian populations. Genet. 16, 97-159. 